Poznańskie Studia Teologiczne 29(2015), s. 239-248. doi: $10.14746 /$ pst.2015.29.14

\author{
Bogusław Kochaniewicz ${ }^{1}$ \\ Uniwersytet im. Adama Mickiewicza w Poznaniu \\ Wydział Teologiczny
}

\title{
Teologia polska oczami rzymianina
}

Przedstawienie tematu podjętego w niniejszym opracowaniu domaga się naprawdę dobrej znajomości stanu teologii w Polsce, a wypowiadający te słowa całą swoją formację (studia licencjackie i doktoranckie) odbył na Zachodzie, co więcej, następnych 10 lat pracował jako wykładowca Papieskiego Uniwersytetu św. Tomasza „Angelicum” w Rzymie, prowadząc zajęcia z teologii dogmatycznej w sekcjach angielskiej i włoskiej, we wszystkich możliwych cyklach kształcenia.

W tej sytuacji pojawia się pytanie: co można powiedzieć nowego i interesującego na temat, który ma już całkiem sporą bibliografię ${ }^{2}$, w niezwykle ciekawy sposób został przedstawiony przez o. prof. Andrzeja Napiórkowskiego OSSPE podczas VII Kongresu Teologów Polskich w Lublinie w 2004 roku $^{3}$ ?

Zdając sobie sprawę z niedoskonałej znajomości tematu, chciałbym podzielić się osobistymi spostrzeżeniami i uwagami po powrocie do kraju. Refleksja ta może okazać się inspirująca $\mathrm{z}$ tego względu, że została dokonana przez pryzmat prawie 20 lat spędzonych w Wiecznym Mieście.

\section{Teologia w Polsce czy teologia polska?}

Analiza haseł zawartych w encyklopediach, leksykonach i słownikach teologicznych pozwala stwierdzić, że na pojęcie „teologia” składają się tak zwane teologie przymiotnikowe: biblijna, dogmatyczna, fundamentalna, moralna, politycz-

\footnotetext{
${ }^{1}$ Bogusław Kochaniewicz, dominikanin, redaktor „Poznańskich Studiów Teologicznych”.

${ }^{2}$ Zob. m.in.: J. Śliwiński, Teologia w Polsce a polska teologia, Więź 12(494) 1999, s. 121-123; A. Napiórkowski, O uniwersyteckość teologii w Polsce, „W Drodze” nr 5/285(1997), s. 55-64; S.C. Napiórkowski (red.), Szkice o polskiej teologii, Poznań 1988; J. Misiurek W poszukiwaniu tożsamości polskiej teologii, „Roczniki Teologiczno-Kanoniczne” 34(1987), z. 2, s. 99-110; D. Oko, Teologia w polskim Kościele, „Znak” nr 472(1994), s. 100-109.

${ }^{3}$ A. Napiórkowski, Teologia polska wobec wyzwań współczesności, w: Rada Naukowa Konferencji Episkopatu Polski, Kościół w życiu publicznym. Teologia polska i europejska wobec nowych wyzwań, t. 1, Lublin 2004, s. 33-64.
} 
na, wyzwolenia, feministyczna, śmierci Boga ${ }^{4}$. Natomiast, gdy chodzi o wątek polski, zazwyczaj w publikacjach tego typu pojawia się hasło „Teologia w Polsce". Takie rozwiązanie proponuje na przykład Religia. Encyklopedia PWN Należy wspomnieć, że wspomniane określenie (teologia w Polsce) jest też tytułem czasopisma Polskiego Towarzystwa Dogmatyków.

Pobieżna analiza hasła „Teologia w Polsce” pozwala dostrzec, że w wyżej wymienionych publikacjach dokonano przeglądu sytuacji współczesnej teologii w Polsce, wymieniając ośrodki teologiczne w Polsce, charakteryzując ich specyfikę oraz wymieniając teologów w nich pracujących. Wobec takiego ujęcia zagadnienia warto postawić pierwsze ważne pytanie. Zawężenie aktywności teologów do granic naszego kraju sprawia, że automatycznie wykluczeni zostają polscy teologowie katoliccy pracujący poza jego granicami, prowadzący wykłady z teologii na uczelniach katolickich we Włoszech (Rzymie), w Austrii, w Niemczech, na Ukrainie, w Rosji, w Izraelu, w Kanadzie, w Stanach Zjednoczonych, w Japonii, w Republice Południowej Afryki, w Australii. Ich nazwisk nie odnotowują żadne leksykony, encyklopedie teologiczne wydawane w naszym kraju. Czy wobec tego nie lepiej posługiwać się pojęciem „teologia polska” zamiast „teologia w Polsce"?

Tak postawione pytanie implikuje kolejne, które zabrzmi nieco prowokacyjnie: czy istnieje polska teologia? Być może niektórzy odpowiedzą, że aktywność rodzimych teologów przejawiająca się w obfitości artykułów publikowanych na łamach polskich periodyków jest dobitnym świadectwem jej istnienia. Kiedy jednak zapytamy się o specyficzne cechy, jakimi odznacza się polska teologia, to pytanie powraca niczym bumerang. Czym bowiem szczególnym wyróżnia się teologia uprawiana nad Wisłą od teologii niemieckiej, włoskiej, francuskiej, chińskiej czy afrykańskiej? Czy jesteśmy w stanie wymienić oryginalne cechy charakteryzujące teologiczną myśl w naszym kraju, która wyróżnia nas na tle refleksji podejmowanych i uprawianych w krajach Europy Zachodniej?

Odpowiedź na powyższe pytania nie napawa optymizmem. Gdyby zapytano wykładowcę akademickiego reprezentującego rzymską uczelnię kościelną, z czym kojarzy się polska teologia, nie powiedziałby ani słowa. Nie wymieniłby nazwiska ani jednego polskiego teologa. W tym miejscu należy wypowiedzieć szokującą dla niektórych osób prawdę: teologia polska widziana z perspektywy Rzymu nie istnieje. O ile niektórzy zachodni wykładowcy potrafią określić dość ogólnie specyfikę teologii włoskiej, niemieckiej czy hiszpańskiej, wymieniając ich reprezentantów, to nie są w stanie podać nikogo z terenu Polski. O czym to może świadczyć? Być może, o nijakości polskiej teologii, braku wyrazu, własnej

${ }^{4}$ Zob. Religia. Encyklopedia PWN, t. 9, Warszawa 2003; Encyklopedia katolicka, t. 19, Lublin 2013.

${ }^{5}$ M. Wojciechowski, Teologia w Polsce, w: Religia. Encyklopedia PWN, t. 9, Warszawa 2003, s. $266-267$. 
oryginalności i tożsamości w takim stopniu, że trudno ją zauważyć i wyróżnić na tle teologii niemieckiej, francuskiej czy włoskiej. Przedstawione obserwacje potwierdza ostra dysproporcja rysująca się pomiędzy liczbą zagranicznych teologów zapraszanych do wygłoszenia referatów na kongresach organizowanych w Polsce, a śladową liczbą polskich prelegentów proszonych o wygłoszenie referatów poza granicami kraju. W tym kontekście warto zapytać się o przyczynę tego stanu rzeczy. Odpowiedź na to pytanie jest złożona.

\section{Język polski barierą nie do przebycia}

Jedną z istotnych przyczyn, wpływających na zaistniały stan rzeczy, jest z całą pewnością bariera językowa. Należy stwierdzić, że najważniejsze polskie czasopisma teologiczne docierają do Rzymu. Niestety, większość z nich proponuje zachodniemu czytelnikowi teksty w języku polskim zaopatrzone $\mathrm{w}$ abstrakty po angielsku, niemiecku bądź włosku. Wobec nieznajomości naszego języka nikt nie czyta dołączonych na końcu streszczeń obcojęzycznych, ponieważ nie informują one w satysfakcjonujący sposób o treści opublikowanych artykułów. Przekłada się to na nieobecność polskojęzycznych publikacji w zestawieniach bibliografii tematu zawartych w obcojęzycznych artykułach.

Innym powodem nieznajomości polskiej teologii jest stosunkowo mała liczba artykułów publikowanych przez rodzimych teologów w czasopismach zachodnich. Przyczyn tej sytuacji można upatrywać w nieuzasadnionych obawach autorów polskich o zbyt wygórowane standardy oceny, co z kolei mogłoby się wiązać z niezakwalifikowaniem zgłoszonego tekstu do publikacji. Na podstawie kilkuletniego doświadczenia redaktora naczelnego międzynarodowego czasopisma teologicznego wychodzącego w Rzymie mogę stwierdzić, że przedstawiciele innych nacji bez żadnych obaw przesyłali swoje teksty niejednokrotnie do kilku redakcji czasopism jednocześnie i nie przejmowali się zbytnio, gdy artykuł nie został przyjęty. Po dokonaniu odpowiednich korekt przesyłali ponownie tekst, który był wydawany.

Przy okazji nie sposób wyrazić pewnego zdziwienia: skoro wielu polskich studentów chlubi się ukończeniem europejskich katolickich uczelni, skoro ich doktoraty zostały napisane i obronione $\mathrm{w}$ językach obcych, to dlaczego $\mathrm{w}$ tak znikomym stopniu publikują wyniki swoich badań na łamach zachodnich czasopism teologicznych?

Dlatego należy popierać apel o publikowanie polskich wyników badań w periodykach zagranicznych klasyfikowanych na tzw. liście ERIH. Bez tłumaczeń polskiej literatury teologicznej na języki kongresowe, bez publikacji wyników badań w zachodnich czasopismach polska teologia nadal będzie nieznana, podręczniki, encyklopedie, słowniki będą zatrzymywać się na prezentowaniu nurtów i prądów teologii w Niemczech, a obszar pomiędzy Odrą a Bugiem będzie pozostawał nadal białą plamą. 


\section{Podejmowana tematyka badań}

Analiza niektórych tytułów polskich publikacji pozwala zauważyć, że obok tekstów wartościowych, które powinny zostać zaprezentowane czytelnikowi zachodniemu, jest wiele takich, które cechuje eklektyzm, schematyzm, brak oryginalności. $Z$ jednej strony należy się cieszyć tym, że w ostatnim czasie dokonano w naszym kraju solidnej charakterystyki oraz popularyzacji osiagnięć znanych zachodnich teologów XX i XXI wieku, w tym również bogatego w treść nauczania św. Jana Pawła II. Należy z uznaniem podkreślić, że w kraju nad Wisłą przesłanie zawarte $\mathrm{w}$ dokumentach papieża Polaka stało się przedmiotem gruntownych badań rodzimych teologów.

$\mathrm{Z}$ drugiej natomiast należy wyrazić obawę, czy w niektórych przypadkach autorzy publikacji, obierając pole swoich badań, nie wybrali najłatwiejszej drogi; kryjąc się za autorytetem wybranych teologów, papieży, dokumentów Magisterium Kościoła, posługując się metodą analityczno-krytyczną, nie ograniczyli się do wiernego opisu takiej bądź innej kwestii? Spisy treści polskich czasopism roją się od tytułów typu: Nadzieja w encyklice „Spe salvi” bądź Tytut „Królowa aniołów" we wspótczesnych dokumentach Magisterium Ecclesiae itd. Pojawia się pytanie: co szczególnie oryginalnego wnoszą wymienione tytuły? Czy nie potwierdzają one tezy o odtwórczym, schematycznym charakterze niektórych publikacji polskiej teologii? Po lekturze niektórych artykułów odnosi się wrażenie, że ich autorzy unikają konfrontacji z prawdziwymi wyzwaniami stającymi wobec współczesnej teologii, boją się poszukiwania nowych sposobów interpretacji, nowych oryginalnych rozwiązań, nieznanych na Zachodzie. Wydaje się, że teologia uprawiana $\mathrm{w}$ naszym kraju powinna $\mathrm{w}$ szerszym niż dotychczas zakresie odpowiadać na współczesne wyzwania i zagrożenia. W tym kontekście jawi się kolejne pytanie: w jakiej mierze teologowie starają się odpowiadać na znaki czasu, na niepokojące prądy, trendy, które pojawiają się w rodzimej kulturze? $\mathrm{Na}$ ile zaś ich refleksja jest odizolowana od rzeczywistości, w której żyjemy?

Poruszona kwestia wiąże się ściśle z kolejnym, nie mniej ważnym problemem: w jaki sposób uczy się studentów refleksji teologicznej w naszym kraju? Czy jest to zachęta do twórczego myślenia, do poszukiwania rozwiązań teologicznych problemów? Czy przypadkiem w wyborze tematów prac magisterskich, doktorskich, a nawet niektórych habilitacyjnych, nie dominuje tendencja streszczania myśli wybranego autora? Należy stwierdzić, że wiele powstałych prac potwierdza wyrażane wątpliwości. Dlatego, z pewną dozą niepokoju należy stwierdzić, że jeżeli nie zostanie zmieniony ten stan rzeczy, to w najbliższej przyszłości kolejne pokolenia wykładowców będą w podobny sposób uprawiały teologię w naszym kraju.

Analiza teologii uprawianej w Polsce pozwala zaobserwować jeszcze inne niepokojące zjawisko, mianowicie, słabe i niewystarczające przełożenie osiągniętych owoców teologicznych badań na duszpasterską praktykę; znikome wykorzy- 
stanie osiagniętych wyników w programach duszpasterskich, kazaniach, konferencjach, katechezach. W jaki sposób zmienić ten stan rzeczy? Kto powinien być odpowiedzialny za tego typu aplikacje? W jaki sposób zachęcić księży przygotowujących niedzielne kazania do sięgnięcia nie tylko po materiały duszpasterskie, lecz po artykuły polskich specjalistów z zakresu teologii biblijnej? Trudno w krótkim artykule odpowiedzieć na postawione pytania.

\section{Polska rzeczywistość}

Oceniając polską teologię, nie sposób pominąć milczeniem warunków, w jakich pracują jej rodzimi twórcy. W porównaniu z nimi ich zachodni koledzy mają komfort czasu na prowadzenie badań naukowych. Teologowie pracujący na uczelniach rzymskich nie wiedza, co to znaczy wypełnianie sylabusów, nie znają trudu wypełniania sprawozdań z badań statutowych, nie piszą artykułów w celu uzyskania jak największej liczby punktów. Koncentrują się natomiast na tym, aby jak najlepiej przeprowadzić badania, co w konsekwencji przekłada się na jakość ich publikacji. Wspaniale zaopatrzone biblioteki kościelne Wiecznego Miasta dopełniają całości obrazu. O ile polski teolog coraz więcej czasu musi poświęcać na pracę o charakterze administracyjnym, o tyle jego zachodni kolega może spokojnie pracować nad kolejną publikacją. Nie dziwi zatem, że rodzimy teolog, żyjąc w pośpiechu, dzieląc swój czas na wiele najprzeróżniejszych obowiązków, ulega niejednokrotnie pokusie podejmowania tematów prostych, nieskomplikowanych, o niskiej czasochłonności, po to, aby zdobyć kolejne punkty za publikację, a w konsekwencji wpisać kolejną pozycję do dorobku. Jakość takich publikacji schodzi oczywiście na dalszy plan.

\section{Cudze chwalicie - swego nie znacie}

Niesprawiedliwe byłoby twierdzenie, że polska teologia jest pozbawiona ciekawych i oryginalnych osiagnięć. Należy jednak stwierdzić, że często dokonania rodzimych teologów nie są szerzej znane w naszym kraju. Wspomniana nieznajomość wynika między innymi z braku szerokiej informacji o nowych cennych publikacjach oraz ich solidnej, obiektywnej oceny. Przegląd recenzji zamieszczanych w polskich czasopismach pozwala zauważyć, że niejednokrotnie oceniane są pozycje, które nie zawsze reprezentują wysoki poziom naukowy, natomiast pomija się milczeniem te, które są wartościowe. W tym kontekście pojawia się pytanie: dlaczego zachodni teologowie stosunkowo szybko potrafią dostrzec na rynku wydawniczym pozycje wartościowe, zamieścić ich recenzje w periodykach teologicznych, informując o ich wartości pozostałych kolegów, a w Polsce jest to niemożliwe? Czy nie kryje się za tym pewnego rodzaju intelektualne lenistwo? Przykładów nie brakuje. 
W roku 1998 została opublikowana dysertacja doktorska, oceniona przez rzymską uczelnię na summa cum laude. Monografia, napisana w języku włoskim, prezentowała po raz pierwszy mariologię św. Piotra Chryzologa. Książkę wysłano do kilkunastu redakcji czasopism zachodnich oraz polskich. Jaki był tego efekt? Autor otrzymał kilkanaście pochlebnych recenzji z Hiszpanii, Francji, Belgii, Niemiec, o Włoszech nie wspominając. W Polsce żadne z czterech czasopism nie zamieściło jej oceny. Dzisiaj, dzięki zachodnim recenzjom, niniejsza praca jest cytowana we wszystkich liczących się publikacjach oraz współczesnych tłumaczeniach kazań Chryzologa ukazujących się na Zachodzie. Niewytłumaczalna inercja oraz niewydolny system informowania o nowościach wydawniczych z zakresu teologii w Polsce powoduje, że nie jesteśmy w stanie dostrzec, a w konsekwencji docenić wielu naprawdę cennych pozycji rodzimych autorów i cieszyć się nimi. Pośród wielu przykładów, które można w tym miejscu przytoczyć, wymienię jedynie dwa.

Kilka lat temu dane mi było uczestniczyć w obronie doktoratu Marty Kwaśnickiej na UPJPII w Krakowie. Praca, poświęcona roli XVIII-wiecznej muzyki w ewangelizacji Indian Moxo, żyjących na terenach dzisiejszej Boliwii, została oparta na nieopublikowanych do tej pory manuskryptach, które są sukcesywnie odkrywane przez promotora, który jako misjonarz pełni posługę duszpasterską pośród mieszkających w dżungli boliwijskich Indian. Dysertacja jest wyjątkowa i przełomowa, zmienia spojrzenie nie tylko na kulturę wspomnianych Indian, ale również na metody ewangelizacji w okresie jezuickich redukcji. Opublikowana w Polsce, w niewielkim nakładzie ${ }^{6}$, do tej pory nie została zauważona; nie doczekała się żadnej recenzji na łamach polskich czasopism. Gdyby ukazała się drukiem na przykład w Hiszpanii, z pewnością miałaby już drugie bądź trzecie wydanie.

Przykład drugi. W roku 2008 na Papieskim Uniwersytecie św. Tomasza z Akwinu „Angelicum” w Rzymie została obroniona praca doktorska polskiego dominikanina, będąca edycją krytyczną dwóch nieznanych i nieopublikowanych do tej pory średniowiecznych traktatów poświęconych niepokalanemu poczęciu Najświętszej Maryi Panny. Dysertacja, napisana w języku francuskim, była tak dobra, że nie tylko została oceniona na summa cum laude przez władze rzymskiej uczelni, ale również zdobyła prestiżową nagrodę Henriego de Lubaca, fundowaną przez Ambasadę Francuską przy Stolicy Apostolskiej dla najlepszego doktoratu $\mathrm{w}$ języku francuskim powstałego na uczelniach rzymskich $w$ ostatnich latach. Niedawno doktorat ten został opublikowany w naszym kraju przez wydawnictwo Instytutu Tomistycznego oo. Dominikanów w Warszawie 7 . Ponieważ

\footnotetext{
${ }^{6}$ M. Kwaśnicka, Wtórna kolonizacja: rola gatunku literacko-muzycznego villancico $w$ ewangelizacji Indian Moxo, Poznań 2010.

${ }^{7}$ P. Krupa, Une grave querelle. L'Université de Paris, les Mendiants et la Conception Immaculée de la Vierge (1387-1390), Warszawa 2013.
} 
byłem recenzentem tej pracy, łatwo mi przyszło ocenić książkę ${ }^{8}$. Niestety, należy stwierdzić, że poza wspomnianą recenzją nie odnotowano w kraju nad Wisłą żadnej innej reakcji. Takich przykładów jest znacznie więcej. Pozwalają one w tym miejscu przytoczyć znane przysłowie: „cudze chwalicie, swego nie znacie, sami nie wiecie, co posiadacie".

\section{Czy istnieją cechy wyróżniające polską teologię?}

Zastanawiając się nad specyfiką polskiej teologii, warto zadać pytanie: czy ma ona jakieś własne, oryginalne cechy, które są nieznane na Zachodzie. Środowisko naukowe Katolickiego Uniwersytetu Lubelskiego wskaże na teologię personalistyczną ks. prof. Czesława Bartnika, teologowie z Katowic wymienią teologię ks. prof. Jerzego Szymika. Ponieważ autorzy ci nie są znani zachodnim czytelnikom, dlatego ich najważniejsze dzieła powinny zostać przetłumaczone i opublikowane na Zachodzie. Wśród kolejnych znanych mi oryginalnych polskich dokonań nie sposób nie wymienić odkrycia specyficznej polskiej teologii ikony, która jest odmienna od prawosławnej, o której pisał o. S.C Napiórkowski OFMConv ${ }^{9}$. Na podstawie bogatych treści związanych z pobożnością maryjną $\mathrm{w}$ jasnogórskim sanktuarium została wypracowana oryginalna teologia sanktuarium, nieznana na Zachodzie ${ }^{10}$. Nie sposób nie wspomnieć o oryginalnej teologii maryjnego zawierzenia, rozpowszechnionej przez św. Jana Pawła II. Czyż to nie jest powód do chluby?

Jestem przekonany, że takich elementów określających specyfikę polskiej teologii jest znacznie więcej. Nie sposób nie dostrzec faktu, że Polska znajduje się na przecięciu dwóch kręgów kulturowych chrześcijaństwa: zachodniego i wschodniego. Z tego też względu tylko w naszym kraju celebruje się zachodnie wniebowzięcie i wschodnie zaśnięcie Najświętszej Maryi Panny (polskie kalwarie). Tylko na naszym terenie zachodni kult figur łączy się ze wschodnim kultem obrazów. Specyfikę polskiej pobożności i duchowości wyznaczają między innymi nieznane na Zachodzie roraty i gorzkie żale. Nikt na Zachodzie nie wie o dorocznych wielotysięcznych spotkaniach modlitewnych młodzieży na Lednicy. Warto zatem, badając specyfikę polskiej pobożności, dostrzec ów specyficzny koloryt i uwzględnić go w teologicznej refleksji.

${ }^{8}$ Zob. Poznańskie Studia Teologiczne 27(2013), s. 245-246.

${ }^{9}$ S.C. Napiórkowski, Polska teologia ikony? Problem obecności Maryi pośród nas w świetle doświadczeń peregrynacyjnych, w: Przewodniczka. Kult Matki Boskiej w Polsce od „Lumen gentium” do „Redemptoris Mater” (1964-1987). Akta VI Ogólnopolskiego Kongresu Mariologicznego i Maryjnego. Częstochowa-Jasna Góra 20-23 IX 1990, Jasna Góra-Częstochowa 1994, s. 95-111.

${ }^{10}$ K. Mroczek, Il Santuario della Madre di Jasna Gora nell'insegnamento di Giovanni Paolo II. Verso una „Teologia del Santuario”, Roma 1996. 


\section{Popularyzacja i wspólpraca}

Gdy dochodzimy do tematu rozpowszechniania informacji na temat aktywności teologów w Polsce, należy z uznaniem podkreślić wielką liczbę funkcjonujących stron internetowych. Mają je krajowe towarzystwa, stowarzyszenia, wydziały teologiczne, o czasopismach z zakresu teologii nie wspomnę. Strony te są lepiej lub słabiej zarządzane przez webmasterów, którzy niejednokrotnie z powodu wielu innych zadań nie zawsze mają wystarczająco wiele czasu, aby poświęcić go na moderowanie. W konsekwencji zawierają one nieaktualne bądź niepełne dane, z czego liczba świeżych informacji często sprowadza się do minimum. W zaistniałej sytuacji pojawia się pytanie: czy nie byłoby wskazane stworzenie jednej ogólnopolskiej strony, która integrowałaby środowisko teologiczne w Polsce, stanowiąc swoiste forum wymiany myśli oraz informacji? Chodziłoby o swoistą elektroniczną tablicę, na której każdy mógłby śledzić, co się dzieje w poszczególnych ośrodkach teologicznych w Polsce, jak przebiegają prace towarzystw naukowych, zapoznać się z informacjami o nowościach wydawniczych krajowych teologów, poznać biogramy nowo wypromowanych doktorów, habilitantów. Strona ta, wyposażona w automatyczne odniesienia na strony internetowe wydziałów teologicznych w Polsce, towarzystw biblistów, dogmatyków, patrologów, moralistów, pastoralistów, informowałaby, bez konieczności odwiedzania wielu stron poszczególnych stowarzyszeń, o wielorakich inicjatywach podejmowanych w Polsce.

\section{Zakończenie}

Konkludując, warto sformułować kilka praktycznych wniosków i postulatów.

1. Aby teologia w Polsce była znana na Zachodzie, należy zadbać o to, aby publikacje krajowych teologów były thumaczone i wydawane w zagranicznych czasopismach teologicznych. Bez prezentacji ich osiagnięć teologia polska nadal będzie nieznana.

2. Warto zwrócić uwagę na polskich teologów pracujących poza granicami naszego kraju. Jest to środowisko w Polsce praktycznie nieznane, podobnie jak jego dorobek. Wskazane byłoby opracowanie swoistego leksykonu polskich wykładowców akademickich uprawiających refleksję teologiczną za granicą. Podjęcie z nimi bliższej współpracy byłoby z całą pewnością ubogacające dla teologii w Polsce.

3. Warto zainicjować w naszym kraju ogólnopolski program naukowy poświęcony badaniom specyfiki teologii polskiej. W ten sposób, poznając elementy wyróżniające naszą teologię spośród innych uprawianych na Zachodzie, łatwiej byłoby rozwijać rodzima specyficzna myśl teologiczna.

4. Należy położyć nacisk, aby w podejmowanych badaniach w większym niż dotychczas stopniu dokonywało się przejście od tematów opartych na 
analizie źródeł do stawiania istotnych problemów teologicznych i poszukiwania ich rozwiązań. Warto uczulać teologów na oryginalność i aktualność podejmowanych tematów badawczych, które powinny odpowiadać na problemy współczesnych chrześcijan w Polsce.

5. Należy zadbać o popularyzację osiagnięć polskich teologów. Często wartościowe publikacje, wydawane w nakładzie 100 egzemplarzy, są nieobecne na półkach księgarni katolickich w Polsce, a o ich istnieniu wie jedynie waskie grono wtajemniczonych.

6. Nie sposób nie zwrócić większej uwagi na rolę recenzji wartościowych pozycji z zakresu teologii publikowanych w naszym kraju. Chociaż publikowanie recenzji nie jest premiowane punktami, to jednak pełnią one ważną funkcję w upowszechnianiu i popularyzacji ciekawych i godnych polecenia pozycji na polskim rynku teologicznym.

\section{Streszczenie}

Artykuł zatytułowany Teologia polska oczami rzymianina jest owocem refleksji autora nad teologią w Polsce, po blisko 20-letnim pobycie w Wiecznym Mieście. Obok wielu krytycznych spostrzeżeń zawiera również propozycje rozwiązania dostrzeżonych problemów. Tekst zwraca uwagę na konieczność prezentacji i popularyzacji wyników badań polskich teologów w zachodnich czasopismach teologicznych. Akcentuje również konieczność recenzowania godnych polecenia publikacji oraz oryginalnych wyników badań, ukazujących się w Polsce. Podkreśla konieczność stworzenia centralnej strony internetowej, która gromadziłaby informacje o aktywności poszczególnych ośrodków i stowarzyszeń teologicznych w Polsce. Autor artykułu proponuje ponadto podjęcie szerokich badań mających na celu ustalenie oryginalnych cech, wyróżniających polską teologię na tle teologicznej refleksji uprawianej na Zachodzie.

\section{Polish Theology Viewed from a Roman Perspective}

\section{Summary}

The article entitled Polish Theology Viewed from a Roman Perspective is the fruit of the author's reflection on theology in Poland, after a stay of nearly 20 years in the Eternal City. Apart from many critical insights, it also contains several proposals concerning the renewal of the situation. One of them is an urgent necessity to present the results of research made by Polish theologians in the Western theological journals. Moreover, the article underscores the need of publication of reviews, which could indicate the best editions of the theological works and original researches of Polish theologians, appearing in Poland. It suggests the necessity to create a central website which could provide information about the activity of educational centers and theological associations in Poland. The author also proposes that extensive research should be undertaken aimed at establishing the original features, which distinguish Polish theology on the background of theological reflection practiced in the West.

\section{Keywords}

theology, publication, journals, specificity, popularization

\section{Slowa kluczowe}

Teologia, publikacja, czasopisma, specyfika, popularyzacja 


\section{Bibliografia}

Encyklopedia katolicka, t. 19, Lublin 2013.

Krupa P., Une grave querelle. L'Université de Paris, les Mendiants et la Conception Immaculée de la Vierge (1387-1390), Warszawa 2013.

Kwaśnicka M., Wtórna kolonizacja: rola gatunku literacko-muzycznego villancico w ewangelizacji Indian Moxo, Poznań 2010.

Misiurek J., W poszukiwaniu tożsamości polskiej teologii, „Roczniki Teologiczno-Kanoniczne" 34(1987), z. 2, s. 99-110.

Mroczek K., Il Santuario della Madre di Jasna Gora nell'insegnamento di Giovanni Paolo II. Verso una „,Teologia del Santuario”, Roma 1996.

Oko D., Teologia w polskim Kościele, „Znak” nr 472(1994), s. 100-109.

Napiórkowski A., O uniwersyteckość teologii w Polsce, „W Drodze” nr 5/285(1997), s. 55-64.

Napiórkowski A., Teologia polska wobec wyzwań współczesności, w: Rada Naukowa Konferencji Episkopatu Polski, Kościót w życiu publicznym. Teologia polska i europejska wobec nowych wyzwań, t. 1, Lublin 2004, s. 33-64.

Napiórkowski S.C., Polska teologia ikony? Problem obecności Maryi pośród nas w świetle doświadczeń peregrynacyjnych, w: Przewodniczka. Kult Matki Boskiej w Polsce od „Lumen gentium” do „Redemptoris Mater” (1964-1987). Akta VI Ogólnopolskiego Kongresu Mariologicznego i Maryjnego. Częstochowa-Jasna Góra 20-23 IX 1990, Jasna Góra-Częstochowa 1994, s. 95-111.

Napiórkowski S.C. (red.), Szkice o polskiej teologii, Poznań 1988.

„Poznańskie Studia Teologiczne” 27(2013), s. 245-246.

Religia. Encyklopedia PWN, t. IX, Warszawa 2003.

Śliwiński J., Teologia w Polsce a polska teologia, Więź 12(494) 1999, s. 121-123.

Wojciechowski M., Teologia w Polsce, w: Religia. Encyklopedia PWN, t. 9, Warszawa 2003, s. 266-267. 